\title{
PARTISIPASI MASYARAKAT DALAM MENGEMBANGKAN TAMAN POSYANDU SRI REJEKI DI KELURAHAN KOTALAMA KECAMATAN KEDUNGKANDANG
}

\author{
Dewi Citra Larasati \\ Program Studi Administrasi Publik, FISIP, Universitas Tribhuwana Tunggadewi \\ Email: citralarasati311@gmail.com
}

\begin{abstract}
The purpose of the research is to determine the level of comunity participation in developing integreted health service (Taman Posyandu) Sri Rejeki in the Kotalama village. This participation is faced with the low level of education of residents of RW 9 in Kotalama Village. The study used a qualitative method using triangulation data collection techniques, a combination of interviews, observation, and documentation. The sampling technique used is Puporsive Sampling. The results of this research are that community participation is classified into an interactive participation typology and is included in the level of supporting independent community interest or providing support in a variety of ways. Whereas the factors that influence participation are 1) the opportunity provided by the village team's driving force, 2) the willingness of the community to participate in developing integreted health service (Taman Posyandu)and 3) the ability of the community to participate especially to solve various problems faced in developing integreted health service (Taman Posyandu) Sri Rejeki.
\end{abstract}

Keyword: Community participation; integreted health service (Taman Posyandu)

Abstrak: Penelitian ini bertujuan untuk mengetahui tingkat partisipasi masyarakat dalam mengembangkan taman posyandu Sri Rejeki di kelurahan Kotalama. Partisipasi ini dihadapkan dengan rendahnya tingkat pendidikan warga RW 9 Kelurahan Kotalama. Penelitian menggunakan metode kualitatif dengan menggunakan tehnik pengumpulan data triangulasi perpaduan antara wawancara, observasi, dan dokumentasi. Teknik penentuan sampling yang digunakan adalah Puporsive Sampling. Hasil dari penelitian ini adalah partisipasi masyarakat tergolong dalam tipologi partisipasi interaktif dan masuk dalam tingkatan partisipasi supporting independent community interest atau memberikan dukungan dalam berbagai macam hal. Sedangkan faktor yang mempengaruhi partisipasi yaitu 1) adanya kesempatan yang diberikan oleh Tim Penggerak PKK Kelurahan, 2) adanya kemauan masyarakat untuk berpartisipasi mengembangkan Taman Posyandu dan 3) adanya kemampuan masyarakat untuk berpartisipasi terutama untuk menyelesaikan berbagai masalah yang dihadapi dalam mengembangkan Taman Posyandu Sri Rejeki.

Kata Kunci: Partisipasi Masyarakat; Taman Posyandu

\section{PENDAHULUAN}

Posyandu merupakan bentuk peran serta masyarakat di bidang kesehatan yang dikelola oleh kader dengan sasaran seluruh anggota masyarakat. Dalam perkembangannya untuk meningkatkan kualitas posyandu, kegiatannya diintegrasikan dengan program Pengembangan Anak Usia Dini (PAUD) dan Bina Keluarga Balita (BKB) yang disebut sebagai Taman Posyandu. Hal ini diatur dalam Peraturan Menteri Dalam Negeri Nomor 19 Tahun 2011 tentang program Pengintegrasian layanan sosial dasar di Posyandu. Pengintegrasian layanan sosial dasar di Posyandu sebagaimana 
dimaksud tersebut meliputi: 1. Pembinaan mengenai gizi dan kesehatan ibu dan anak; 2. Pengendalian masalah penyakit dan penyehatan lingkungan; 3. prilaku hidup bersih dan sehat; 4. kesehatan lanjut usia; 5. BKB; 6. Pos PAUD; 7. percepatan penganekaragaman konsumsi pangan; 8. pemberdayaan fakir miskin, komunitas adat terpencil dan penyandang masalah kesejahteraan sosial; 9. kesehatan reproduksi remaja; dan 10. peningkatan ekonomi keluarga. Pengintegrasian yang dimaksud adalah suatu upaya Pemerintah dalam mengupayakan supaya berbagai layanan yang diperlukan oleh masyarakat bisa bersinergi, layanan tersebut meliputi perbaikan mengenai kesehatan dan gizi, perbaikan pendidikan dan perkembangan anak, masalah peningkatan ekonomi terutama ekonomi keluarga, perbaikan ketahanan pangan keluarga dan kesejahteraan sosial masyarakat. Sasaran pelayanan ini adalah kesehatan ibu, bayi dan balita.

Provinsi Jawa Timur pada tahun 2013 merupakan salah satu dari sekian banyak provinsi di Indonesia yang berani memasang target pembentukan 10.000 taman Posyandu. Pemerintah Provinsi Jawa Timur sangat peduli dan berupaya keras dalam menangani permasalahan tumbuh kembang anak. Pemerintah Provinsi Jawa Timur menganggap perhatian terhadap pendidikan dan tumbuh kembang anak akan sangat berpengaruh terhadap pembentukan generasi emas Indonesia. Perhatian tersebut, diwujudkan dalam sebuah Peraturan Gubernur Nomor 63 Tahun 2011 tentang Pengembangan Anak Usia Dini Holistik-Integratif, yang bertujuan agar semua anak usia dini di Provinsi Jawa Timur mendapatkan perhatian akan pemenuhan terhadap seluruh kebutuhan esensialnya, sehingga anak-anak usia dini di Provinsi Jawa Timur mampu tumbuh dan berkembang secara optimal sesuai dengan usia dan tahapan perkembangannya.

Kehadiran Taman Posyandu juga untuk mendampingi bagaimana peran ibu dalam memecahkan permasalahan anak yang saat ini semakin kompleks. Taman Posyandu bisa menjadi punggawa terdepan untuk mendampingi dan mengawal pendidikan dan pertumbuhan anak sejak dini. Dengan optimalnya fungsi taman posyandu diharapkan dapat meningkatkan derajat kesehatan masyarakat melalui layanan kesehatan paripurna baik pemenuhan gizi, stimulasi pendidikan sejak dini sesuai usia, pengasuhan oleh orang tua dan perlindungan terhadap anak terutama intervensi pada masa keemasan yaitu pada seribu HPK (Hari Pertama Kehidupan) dalam upaya menciptakan sumber daya manusia yang sehat, cerdas dan produktif.

Kota Malang telah menggalakkan dan mengembangkan Taman Posyandu mulai akhir tahun 2012. Jumlah perkembangan Taman Posyandu dari tahun 2012 sampai dengan 2017 adalah sebanyak 368 (tiga ratus enam pulh delapan) dan yang sudah berjalan optimal sebanyak 143 (seratus empat puluh tiga). Perkembangan tersebut terus meningkat di seluruh kecamatan di Kota Malang hingga awal tahun 2019 menjadi 233 Taman Posyandu. Salah satu Taman Posyandu di Kota Malang yang berkembang sejak 2013 adalah Taman Posyandu Sri Rejeki yang berada di Kelurahan Kotalama Kecamatan Kedungkandang. Pengembangan Taman Posyandu dihadapkan dengan berbagai macam tantangan salah satunya adalah rendahnya tingkat pendidikan masyarakat. Namun, rendahnya tingkat pendidikan tersebut tidak membuat Taman Posyandu Sri Rejeki kemudian tidak berkembang. Partisipasi masyarakat menjadi salah satu faktor dominan yang membuat Taman Posyandu Sri Rejeki tetap ada hingga sekarang. Sehingga berdasarkan latar belakang tersebut, peneliti tertarik untuk mengetahui: 1) partisipasi masyarakat dalam mengembangkan Taman Posyandu Sri 
Rejeki di Kelurahan Kotalama Kecamatan Kedungkandang, dan 2) faktor-faktor yang mempengaruhi partisipasi masyarakat dalam mengembangkan taman posyandu.

Dari dua rumusan masalah tersebut, beberapa teori yang digunakan untuk menganalisis dalam penelitian ini adalah mengenai Partisipasi Masyarakat. Menurut Theresia, et all (2014:196) menjelaskan bahwa pengertian dari partisipasi adalah keikutsertaan seseorang atau sekelompok anggota masyarakat dalam suatu kegiatan. Definisi lain dikemukan oleh Bornby dalam Theresia, et all (2014:196) mengartikan partisipasi sebagai tindakan untuk mengambil bagian yaitu kegiatan atau pernyataan untuk mengambil bagian dari kegiatan dengan maksud memperoleh manfaat. Sehingga dapat disimpulkan bahwa partisipasi yang diberikan, masyarakat menyadari bahwa kegiatan yang ada bukanlah kewajiban yang sekedar dilakukan oleh pemerintah namun juga menuntut keterlibatan masyarakat yang akan diperbaiki mutunya karena disitulah manfaat yang nantinya akan diperoleh. Berikut adalah bentuk-bentuk kegiatan partisipasi masyarakat yang dapat dilakukan oleh warga berupa : 1) menjadi anggota kelompok masyarakat, 2) pelibatan diri dalam kegiatan diskusi kelompok, 3) melibatkan diri dalam kegiatan-kegiatan organisasi untuk menggerakkan partisipasi masyarakat yang lain, 4) menggerakkan sumber daya masyarakat, 5) mengambil bagian dalam hal pengambilan keputusan bersama, 6) memanfaatkan hasil-hasil yang dicapai dari kegiatan masyarakatnya.

Yadav dalam Theresia, et all (2014: 198-199) juga mengemukakan bahwa ada empat macam kegiatan yang menunjukkan partisipasi masyarakat di dalam kegiatan pembangunan, yaitu 1) partisipasi dalam hal pengambilan keputusan, 2) partisipasi dalam hal pelaksanaan kegiatan, 3) partisipasi dalam hal pemantauan dan evaluasi pembangunan, serta 4) partisipasi dalam hal pemanfaatan hasil pembangunan. Slamet dalam Mardikanto dan Poerwoko (2017:84-85) mengemukakan adanya keberagaman bentuk partisipasi berdasarkan input yang disumbangkan dan keikutsertaannya dalam memanfaatkan hasil pembangunan. Seperti tabel berikut ini:

Tabel 1. Ragam Partisipasi Masyarakat

\begin{tabular}{|l|c|c|c|c|c|}
\hline \multirow{2}{*}{\multicolumn{1}{c|}{ Partisipasi yang ditunjukkan }} & \multicolumn{5}{c|}{ Ragam Partisipasi } \\
\cline { 2 - 7 } & $\mathbf{1}$ & $\mathbf{2}$ & $\mathbf{3}$ & $\mathbf{4}$ & $\mathbf{5}$ \\
\hline Memberikan Input & + & + & + & - & + \\
\hline Menerima Imbalan atas input yang diberikan & + & - & + & - & - \\
\hline Menikmati manfaat hasil & + & + & - & + & - \\
\hline
\end{tabular}

Sumber: Mardikanto dan Poerwoko (2017:85)

Dari kelima macam keragaman partisipasi tersebut di atas bentuk nomer 1 sampai dengan 5 , bentuk pertisipasi masyarakat nomer 2 seharusnya lebih banyak dikembangkan, dan bentuk nomer 1 hanya diberlakukan bagi masyarakat lapisan bawah. Sedangkan partisipasi bentuk nomer 5 tidak bisa diharapkan pada masyarakat lapisan bawah. Di samping itu, model partisipasi nomer 4 seharusnya tidak boleh terjadi, meskipun pada prakteknya hal ini sangat sulit dihindari.

Dilihat dari tingkatan atau tahapan partisipasi, Wilcox dalam Theresia, et all (2014:202) mengemukakan ada lima tingkatan atau tahapan, yaitu:

1. Memberikan informasi (information) yaitu memberikan pengetahuan atau informasi kepada masyarakat bisa ikut serta berpartisipasi. 


\section{REFORMASI}

ISSN 2088-7469 (Paper) ISSN 2407-6864 (Online)

Volume 9 Nomor 1 (2019)

2. Konsultasi (consultation) yaitu menawarkan berbagai macam pendapat, bertindak sebagai pendengar yang baik untuk memberikan umpan balik, namun tidak ikut terlibat dalam implementasi ide dan gagasan tersebut.

3. Pengambilan keputusan bersama (deciding together) yaitu memberikan dukungan terhadap ide yang muncul, gagasan yang ada, serta pilihan-pilihan dan mengembangkan peluang yang diperlukan guna mengambil keputusan.

4. Bertindak bersama (acting together) yaitu pada tahapan ini, tidak hanya sekedar ikut dalam pengambilan keputusan tetapi juga ikut terlibat dan menjalin kemitraan dalam pelaksanaan kegiatannya.

5. Memberikan dukungan (supporting independent community interest) dimana kelompok-kelompok lokal yang ada menawarkan pendanaan, menawarkan nasehat, dan menawarkan dukungan lain untuk mengembangkan agenda kegiatan.

Gambar 1. Jenjang Tingkat Partisipasi (Wilcox, 1988)

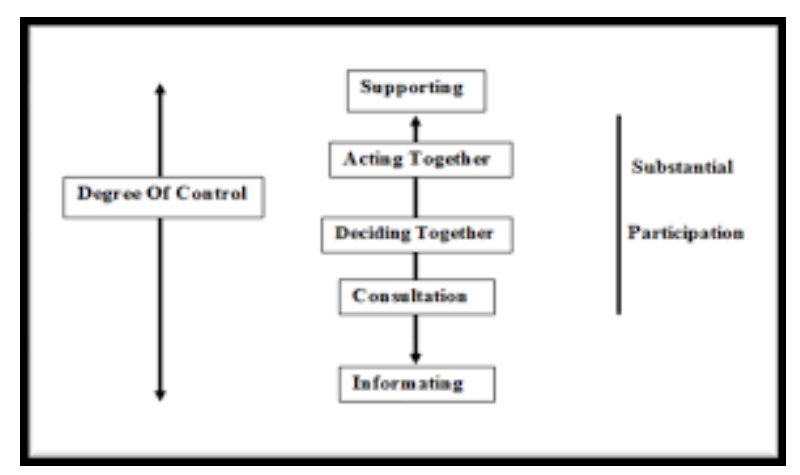

Sumber: Theresia, et all (2014:202)

Faktor-faktor yang mempengaruhi tumbuh dan berkembangnya partisipasi masyarakat ditentukan oleh tiga unsur pokok, hal ini dijelaskan oleh Slamet dalam Theresia, et all (2014:207) yaitu: 1) adanya kesempatan yang diberikan kepada masyarakat, 2) adanya kemauan masyarakat untuk berpartisipasi, dan 3) adanya kemampuan masyarakat untuk berpartisipasi. Berikut ini adalah ilustrasi gambar mengenai tiga unsur pokok syarat tumbuh dan berkembangnya partisipasi masyarakat. Adanya kesempatan yang diberikan, sering merupakan faktor pendukung tumbuhnya kemauan dan kemauan akan sangat menentukan kemampuannya:

Gambar 2. Syarat dan Tumbuhnya Partisipasi Masyarakat

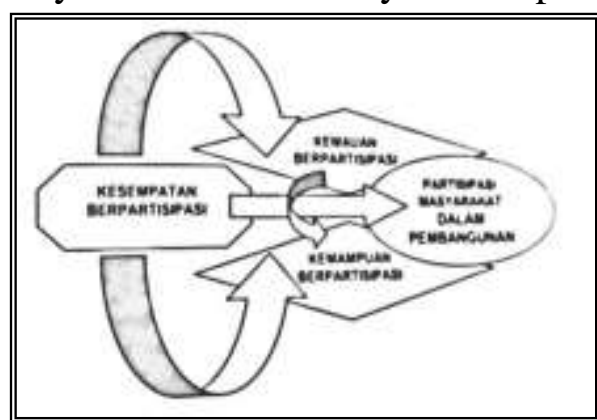

Sumber: Mardikanto dan Poerwoko (2017:91) 


\section{REFORMASI}

ISSN 2088-7469 (Paper) ISSN 2407-6864 (Online)

Volume 9 Nomor 1 (2019)

Di samping itu, ada beberapa faktor-faktor yang berpengaruh terhadap tumbuh dan berkembangnya partisipasi masyarakat dalam pembangunan, juga didekati dalam berbagai pendekatan disiplin keilmuan, sebagaimana berikut:

Gambar 3. Faktor-Faktor yang Berpengaruh terhadap Tumbuh-Kembangnya Partisipasi

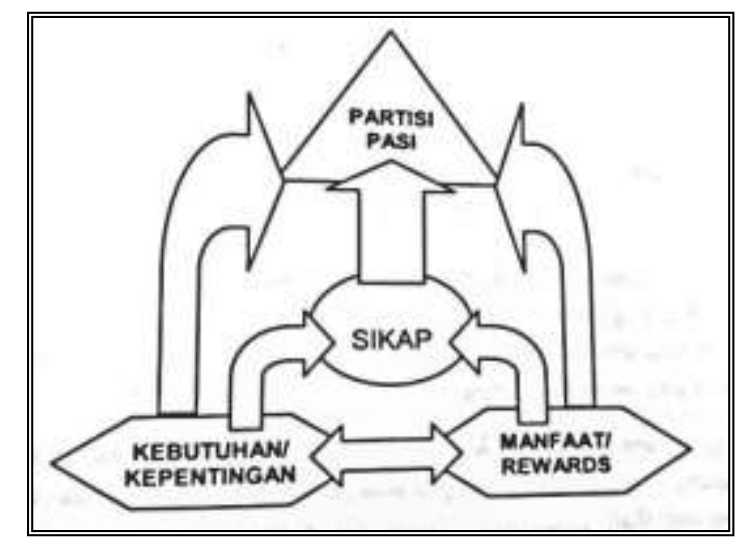

Sumber: Mardikanto dan Poerwoko (2017:93)

Mardikanto dan Poerwoko (2017:93-94) mejelaskan gambar di atas berdasarkan pendekatan disiplin ilmu adalah sebagai berikut:

a) Dalam konsep psikologi, tumbuh dan berkembangnya partisipasi masyarakat, sangat ditentukan oleh motivasi yang melatarbelakanginya, yang merupakan cerminan dan dorongan, tekanan, kebutuhan, keinginan dan harapan-harapan yang dirasakan.

b) Secara sosiologis, sikap merupakan fungsi kepentingan.

c) Dengan demikian tumbuh dan berkambangnya partisipasi dalam masyarakat, akan sangat ditentukan oleh persepsi masyarakat terhadap tingkat kepentingan dari pesan-pesan yang disampaikan kepadanya.

d) Menurut konsep pendidikan, partisipasi merupakan tanggapan atau respon yang diberikan terhadap setiap rangsangan atau stimulus yang diberikan, yang dalam hal ini, respon merupakan fungsi dari manfaat atau reward yang dapat diharapkan.

e) Besarnya harapan dalam konsep ekonomi, sangat ditentukan oleh besarnya peluang dan harga dari manfaat yang akan diperoleh.

f) Tentang manfaat itu sendiri, dapat dibedakan dalam manfaat ekonomi maupun non ekonomi (yang dapat dibedakan dalam: kekuasaan, persahabatan/kebersamaan, dan prestasi).

Selain terdapat faktor-faktor yang mempengaruhi tumbuh dan berkembangnya partisipasi masyarakat, Soetrisno dalam Theresia, et all (2014:211-212) mengidentifikasi beberapa masalah yang ada kaitannya dengan pengembangan partisipasi masyarakat dalam pembangunan, yaitu:

1. Belum dipahaminya makna sebenarnya tentang partisipasi oleh pihak perencana dan pelaksana. 
a. Pada tataran perencana, partisipasi diartikan sebagai kemauan masyarakat untuk secara penuh mendukung pembangunan yang direncanakan dan ditetapkan sendiri oleh aparat pemerintah, sehingga masyarakat cenderung pasif dan hanya sebagai sub-ordinasi pemerintah.

b. Pada tataran pelaksana, pembangunan yang dirancang oleh pemerintah ditetapkan oleh pemerintah didefinisikan sebagai kebutuhan masyarakat. Sedangkan yang dirancang dan ditetapkan masyarakat, didefinisikan keinginan masyarakat yang mempunyai prioritas yang sangat rendah.

c. Partisipasi masyarakat sering didefinisikan sebagai kerjasama pemerintah dan masyarakat yang tidak pernah memperhatikan adanya sub-sistem yang disubordinasikan oleh supra sistem dan aspirasi masyarakat cukup diakomodasikan dalam perencanaan dan pelaksanaan pembangunan.

2. Dikembangkannnya pembangunan sebagai ideologi baru yang harus diamankan dengan dijaga ketat, yang mendorong aparat pemerintah bersifat otoriter. Sehingga menimbulkan reaksi berupa budaya diam dan menimbulkan keengganan masyarakat untuk berpartisipasi.

3. Banyaknya peraturan yang meredam keinginan masyarakat untuk berpartisipasi.

\section{METODE PENELITIAN}

Penelitian ini ingin mengetahui partisipasi masyarakat, sehingga penelitian ini menggunakan metode kualitatif karena menurut Moleong (2015:6) metode penelitian ini bermaksud untuk memahami fenomena tentang apa yang dialami oleh subyek penelitian seperti perilaku, persepsi, motivasi, tindakan, dan lain-lain secara holistik dan dengan cara deskripsi dalam bentuk kata-kata dan bahasa, pada suatu konteks khusus yang alamiah dan dengan memanfaatkan berbagai metode ilmiah. Penelitian kualitatif lebih peka dan dapat menyesuaikan diri dengan kondisi di lapangan, sehingga urutan kegiatan dapat berubah-ubah tergantung kondisi dan gejala-gejala yang ditemukan.

Teknik pengumpulan data merupakan langkah yang paling strategis dalam penelitian, karena tujuan utama dari penelitian adalah mendapatkan data, (Sugiyono,2015:62). Pada penelitian ini peneliti melakukan pengumpulan data melalui Triangulasi. Menurut Sugiyono (2015:83), triangulasi dapat diartikan sebagai sebuah teknik pengumpulan data yang bersifat menggabung dari berbagai teknik pengumpulan data dan sumber yang telah ada di antaranya yaitu melakukan observasi, melakukan wawancara, dan melakukan dokumentasi. Sumber data yang digunakan dalam penelitian ini dengan menggunakan kata-kata dan tindakan (diperoleh saat wawancara dan observasi dengan informan), sumber tertulis (data dari arsip yang ada di taman posyandu Sri Rezeki), foto (dokumentasi) dan data statistik. Menurut Moleong (2015:157).

Teknik pengumpulan data dalam penelitian ini menggunakan teknik purposive sampling yaitu teknik pengambilan sampel sumber data dengan pertimbangan tertentu. Pertimbangan tersebut misalnya orang yang dianggap paling tahu tentang apa yang peneliti harapkan, atau orang tersebut sebagai penguasa sehingga akan memudahkan peneliti menjelajahi objek/situasi sosial yang diteliti, (Sugiyono, 2015:53-54)

Sedangkan analisis data yang digunakan dalam penelitian ini adalah model Miles dan Huberman. Sugiyono (2015:91) menyatakan bahwa aktivitas dalam analisis data 
kualitatif dilakukan secara interaktif dan terus-menerus sampai tuntas, sehingga datanya sudah jenuh. Aktivitas dalam analisis data tersebut yaitu: 1) data reduction, 2) data display, dan 3) conclusion drawing/verification.

\section{HASIL DAN PEMBAHASAN}

\section{Partisipasi Masyarakat Dalam Mengembangkan Taman Posyandu Sri Rejeki di Kelurahan Kotalama Kecamatan Kedungkandang}

Taman Posyandu Sri Rejeki adalah salah satu nama Taman Posyandu yang merupakan Taman Posyandu yang dibimbing Tim Penggerak PKK Kelurahan Kotalama Kecamatan Kedungkandang, dimana taman posyandu ini berada dalam monitoring Pokja 2 dan Pokja 4. Taman Posyandu ini dikelola oleh kelompok PKK RW. 9 bertempat di Balai RW. 9 Jalan Muharto Gang V. Taman Posyandu Sri Rejeki ini terdiri dari Posyandu Balita, pos PAUD dan Bina Keluarga Balita (BKB). Mengembangkan Taman Posyandu bukanlah hal yang mudah, karena terdiri dari tiga program kegiatan yang terintegrasi sekaligus.

Dari tiga program kegiatan tersebut, yang paling aktif adalah kegiatan posyandu. Posyandu di RW. 09 ini tidak hanya Posyandu balita saja, namun ada juga posyandu lansia. Jadwal pelaksanaan posyandu balita dilakukan setiap bulan, hari Rabu minggu ketiga. Dengan dibantu 15 kader posyandu, posyandu Sri Rejeki secara kontinyu bisa memberikan pelayanan kesehatan dengan baik terhadap balita dan lansia yang ada di RW 9. Berjalannya posyandu ini tidak lepas dari kemauan dari para kader dan di dukung oleh pihak Puskesmas Kedungkandang.

Setiap kegiatan posyandu dilaksanakan akan ada petugas puskesmas dan/atau bidan kelurahan yang stand by untuk memberikan berbagai macam pelayanan kesehatan, seperti: penimbangan balita, pengukuran tinggi badan/panjang badan, pemberian imunisasi, konsultasi kesehatan, konsultasi KB, konsultasi tumbuh kembang hingga pemberian makanan tambahan (PMT). Posyandu masuk dalam kewenangan Pokja 4 TP PKK Kelurahan Kotalama, sehingga untuk pelaporan dan segala hal administrasi dikoordinir oleh ketua Pokja 4. Karena setiap posyandu akan mendapat pembinaan dari Dinas Kesehatan.

Pemantauan juga dilakukan oleh PLKB kelurahan. hal ini dilakukan untuk menjaring dan menarik minat ibu-ibu usia produktif dalam program KB. Melihat karakteristik dan mindset mereka masih anti dengan program KB. Bagi kebanyakan masyarakat di RW. 09 masih ada slogan banyak anak banyak rezeki. Di sinilah dibutuhkan kesabaran dari PLKB dan kader posyandu untuk merubah mindset yang telah tertanam tersebut.

Begitu halnya dengan Posyandu Lansia, walaupun terbilang baru dibentuk beberapa tahun ini, namun semangat lansia untuk berpartisipasi hadir sangat tinggi. Pelayanan ini juga bekerjasama dengan Puskesmas Pembantu Kedungkandang yang mendatangkan bidan kelurahan atau petugas medis lainnya jika bidan kelurahan berhalangan hadir. Pelayanan kesehatan yang dilakukan biasanya adalah pengecekan gula darah (cek kolesterol, asam urat dan gula darah), cek tekanan darah (tensi), timbang badan dan konsultasi kesehatan mengenai penyakit, hingga pemberian makanan tambahan seperti susu osteoporosis. Untuk dana operasional kedua posyandu tersebut berasal dari Dinas Kesehatan serta donasi masyarakat ketika mereka datang ke posyandu, baik lansia maupun posyandu balita.

Selain kegiatan Posyandu balita dan posyandu lansia, di Taman Posyandu Sri Rejeki terdapat juga pos PAUD. Di Pos PAUD ini jumlah kadernya adalah lima orang. 
Pos PAUD Sri Rejeki memberikan pelayanan pendidikan usia dini dengan 2 kategori usia. Kategori A untuk anak usia 2-3 tahun dan kategori B untuk anak usia 3-4 tahun. Pos PAUD Sri Rejeki telah memperoleh izin operasional sejak tahun 2013 dan diperpanjang setiap tiga tahun sekali. Secara aturan, kader/guru pos PAUD haruslah sarjana, namun faktanya Kader di Pos PAUD Sri Rejeki tidak ada satupun kader yang memenuhi aturan tersebut. Pos PAUD melakukan pelayanan setiap hari Senin sampai dengan Kamis. Operasionalnyapun berasal dari sumbangan wali murid yang menyekolahkan anaknya ke pos PAUD Sri Rejeki. Untuk memajukan pos PAUD Sri Rejeki, kader pengelola pos PAUD sering mengadakan forum pertemuan wali murid, dengan begitu kader dan wali murid bisa duduk bersama membicarakan tentang apa saja yang hendak dilakukan untuk kemajuan pos PAUD, atau hanya sekedar duduk memberikan saran dan masukan sebagai evaluasi bagi kader-kader pengelola pos PAUD.

Dalam panduan Taman Posyandu, Kegiatan pos PAUD ini harus terintegrasi dengan BKB. Target sasaran dari Pos PAUD adalah pendidikan anak usia dini, sdengakan BKB adalah pembekalan yang diberikan untuk membekali orang tua yang anaknya bersekolah di pos PAUD atau orang tua yang anaknya medapatkan pelayanan kesehatan. Materi pos PAUD ini adalah seputar tumbuh kembang anak, mendidik anak sesuai zamannya. Kareana update ilmu parenting sangat dibutuhkan untuk menghasilkan generasi penerus Indonesia yang gemilang. Seharusnya, ada kader BKB tersendiri, namun karena yang memiliki pengetahuan dan pendidikan lebih mengenai masalah parenting. Sehingga kader BKB juga merangkap dengan kader Pos PAUD.

Sementara jadwal kegiatan BKB biasanya diadakan bersamaan dengan pos PAUD, biasanya setiap bulan sekali, Senin/Kamis minggu ketiga. Karena jadwal pelaksanaan BKB dan Pos PAUD bersamaan, biasanya dalam pengisian mereka bergantian. Jikalau hendak memanggil pemateri, mereka tidak sanggup untuk membayar karena tidak ada dana. Untuk mengatasi masalah pemateri, kader BKB harus pandai untuk meminta tolong (bernegosiasi) supaya pemateri yang mengisi sukarela untuk tidak dibayar. Biasanya kader BKB menggandeng LSM atau dosendosen dan dokter muda.

Pengembangan Taman Posyandu ini adalah bentuk keterlibatan dan keikutsertaan secara aktif dan sukarela, karena alasan-alasan tertentu baik dari dalam diri (instrinsik) maupun dari luar (ekstrinsik) dalam keseluruhan proses kegiatan yang bersangkutan. Hal ini seperti keterlibatan kader taman posyandu baik itu kader posyandu, kader pos PAUD maupun kader BKB. Kader-kader tersebut bekerja karena merasa ingin berguna dan berbuat untuk warga yang ada wilayahnya serta ingin memajukan wilayahnya.

Kawasan RW. 09 Kelurahan Kotalama ini adalah kawasan yang ditinggali oleh sebagian besar warga pendatang yang mana tingkat pendidikan masih sangat rendah, kesadaran akan pentingnya pendidikan dan kesehatanpun juga sangatlah minim, serta masih banyak mindset lama bahwa wanita itu tidak boleh pintar. Tidak heran di RW0. 9 Kelurahan Kotalama ini ada beberapa warga yang masih buta huruf. Dengan latar belakang tersebut, beberapa orang yang sekarang menjadi kader taman posyandu tergerak untuk merubah keadaan lingkungannya tersebut. Dengan kata lain, para kader mempunyai kesadaran untuk memperbaiki mutu hidup warganya.

Forum kegiatan Taman Posyandu ini adalah salah satu bentuk forum yang membuat masyarakat dapat berperan langsung dalam proses pengambilan keputusan tentang program-progam mengenai kesehatan dan pendidikan yang akan dilakukan di 
wilayahnya. Apalagi Taman posyandu ini adalah sinergitas pelayanan kesehatan ibu dan anak (imunisasi, pemberian PMT, pemantauan tumbuh kembang, program KB, kesehatan ibu dan anak), pelayanan kesehatan lansia (kontrol kesehatan, penyuluhan dan konsultasi kesehatan, pemberian PMT, dan sebagainya), pelayanan pendidikan usia dini, hingga pendidikan tumbuh kembang anak untuk orang tua.

Tidak hanya melakukan pengambilan keputusan saja, masyarakat juga ikut serta dalam pelaksanaan kegiatan langsung. Kader Taman Posyandu mengkoordinir pelaksanaan kegiatannya sesuai jadwal. Didukung dengan peran serta masyarakat lainnya, misalnya urunan/sumbangan saat mereka datang pada kegiatan berlangsung, jumputan, dan bentuk lainnya berupa tenaga untuk bergotong royong mensukseskan program ini. Karena dana untuk Taman Posyandu sangatlah minim dari pemerintah baik pusat, provinsi maupun kota.

Tidak hanya dalam hal pengambilan keputusan dan pelaksanaan kegiatan saja, masyarakat RW. 09 Kelurahan Kotalama juga aktif dalam pemantauan dan evaluasi kegiatan Taman Posyandu yang dilakukan secara periodik oleh Tim Penggerak PKK Kelurahan Kotalama, Dinas Kesehatan dan Dinas Pendidikan. Bahkan dalam pengembangan Taman Posyandu, masyarakatpun turut berpartisipasi dalam pemanfaatan hasil kegiatan. Hal ini dengan banyaknya masyarakat yang datang dalam pelaksanaan Posyandu Balita, kurang lebih sebanyak 125 balita, kehadiran para lansia saat posyandu lansia, banyaknya orang tua yang mendaftarkan anknya belajar di Pos PAUD baik yang kategori A maupun B sehingga minimal peserta didik terpenuhi. Hal ini juga terjadi saat adanya penyuluhan BKB, minimal 20 ibu-ibu bisa lebih hadir dalam pertemuan ini. Keinginan mereka untuk mendapatkan manfaat akan ilmu tumbuh kembang anak dan parenting sangatlah tinggi.

Melihat Partisipasi masyarakat di RW. 09 dalam mengembangkan Taman Posyandu Sri Rejeki Kelurahan Kotalama, dapat diketahui bahwa partisipasi masyarakat disini termasuk dalam ragam partisipasi model 2 dimana kader memberikan input dengan ikut serta dalam pengambilan keputusan dan pelaksanaan, namun mereka tidak menerima imbalan atas kerja yang mereka lakukan bahkan mereka cenderung memberikan sumbangsih lebih dan ikut berpertisipasi dana supaya Taman Posyandu ini tetap terus berjalan. Masyarakatpun juga menikmati manfaat hasil dari adanya Taman Posyandu. Padahal menurut Slamet dalam Mardikanto dan Poerwoko (2017:86) bentuk partisipasi level 1 adalah bentuk partisipasi yang dilakukan oleh masyarakat lapis-bawah seperti pada masyarakat RW. 09 Kelurahan Kotalama. Namun hal ini terbantahkan, masyarakat RW. 09 Kelurahan Kotalama malah mampu melaksanakan bentuk partisipasi model 2 yang dianggap adalah bentuk ideal dari 5 model yang ada.

Partisipasi masyarakat dalam pengembangan taman posyandu di RW. 09 Kelurahan Kotalama ini tergolong dalam tingkat partisipasi yang tinggi, bila dianalisis menggunakan gambar bentuk 1 mengenai jenjang tingkat partisipasi masyarakat. Tingkat partisipasi masyarakatnya masuk ke dalam tingkatan partisipasi supporting independent community interest atau tingkat memberikan dukungan dalam segala hal. Dukungan informasi, ide, pengambilan keputusan, menjalin kerjasama bahkan dalam hal dukungan dana. Partisipasi masyarakat model seperti ini adalah tingkat tertinggi sehingga kontrol dalam kegiatanpun sangat baik. Hal ini sangat kontras jika dibandingkan dengan kondisi penduduk yang memiliki tingkat pendidikan yang masih rendah. Mereka malah memiliki kemauan yang besar sehingga tingkat partisipasi 
menjadi sangat tinggi. Jika dimasukkan dalam tipologi partisipasi, karakteristik masyarakat yang ada masuk dalam tipe partisipasi Interaktif.

\section{Faktor-Faktor Yang Mempengaruhi Partisipasi Masyarakat Dalam Mengemba- ngkan Taman Posyandu}

Faktor pertama yang mempengaruhi partisipasi masyarakat RW. 09 Kelurahan Kotalama adalah adanya kesempatan yang diberikan oleh tim penggerak PKK Kelurahan terhadap kader-kader hebat yang ada di kelompok PKK RW. 09 untuk mengembangkan Taman Posyandu Sri Rejeki. Awalnya sangat sulit mencari kader yang benar-benar mau dan mampu untuk mengembangkan Taman Posyandu ini. Mengingat Taman Posyandu ini adalah program yang terintegrasi antara posyandu, pos PAUD dan Bina Keluarga Balita (BKB). Namun dengan kerja keras dan motivasi yang tinggi, tim Penggerak PKK Kelurahan Kotalama sekitar tahun 2013 akhirnya menemukan beberapa kader militan yang siap untuk mengembangkan Taman Posyandu. Dengan adanya motivasi dari ketua TP PKK Kelurahan Kotalama saat itu dan pendampingan yang sangat telaten selama satu tahun membuat para kader terus bersemangat untuk maju. Sosialisasi langsung dilakukan oleh pengurus melalui beberapa forum pertemuan warga baik di tingkat RT, pengajian hingga pertemuan tingkat RW. Tim Penggerak PKK berperan penting saat itu, karena kader muda harus selalu diajak berdiskusi dan diberi saran untuk belajar menjadi lebih baik. Dengan pendampingan serta motivasi tersebut, pertama kalinya pos PAUD berhasil mendapatkan izin operasional dari Diknas dan pelaksanaan pertemuan BKB rutin berjalan hingga tahun ini.

Faktor kedua adalah adanya kemauan masyarakat untuk ikut berpartisipasi. Dilatarbelakangi tingkat pendidikan warga yang sangat rendah, kesadaran akan pendidikan dan kesehatan yang sangat minim karena wilayahnya di pinggir kali, membuat beberapa anak muda yang tergabung menjadi kader taman pusyandu tergerak hatinya untuk merubah nasib wilayahnya. Mereka menyadari bahwa mereka juga berpendidikan rendah, adanya motivasi mendapatkan ilmu gratis dengan belajar berorganisasi membuat taman posyandu yang dirintis ketika tahun 2013 menjadi lebih berkembang pada saat ini. Kemauan inilah yang jarang ditemuai saat ini, mau berjuang untuk kepentingan sosial.

Faktor ketiga adalah adanya kemampuan masyarakat untuk ikut berpartisipasi. Hal ini adalah kekuatan yang dimiliki dalam mengembangkan Taman Posyandu di Kelurahan Kotalama. Kemampuan kader dalam menemukan peluang untuk memperbaiki diri dan lingkungannnya adalah yang paling menonjol. Bagi para kader, mereka bisa menjadi lebih baik dan bermanfaat bagi sekitarnya karena mereka menangkap peluang mengembangkan diri melalu pelatihan, workshop, seminar, atau sosialisasi yang diadakan oleh TP PKK Kota Malang dan Dinas/Badan yang berada di bawah naungan Pemkot Malang. Ada kesempatan beasiswa bagi kader-kader mengikuti kejar paket. Selain itu, kemampuan mereka saling bekerjasama dalam menyelesaikan masalah yang ada, seperti: Ketika salah satu guru pos PAUD tidak bisa mengajar maka bagian admin dan kepala sekolah tidak ragu menggantikannya, atau saat ada beberapa masyarakat yang tidak mendatangi balitanya ke posyandu, maka para kader mengunjungi rumah balita tersebut, bahkan mereka juga sanggup mencari pemateri BKB yang dengan sukarela tidak dibayar ketika mengisi. Ketiga faktor inilah yang mempengaruhi partisipasi masyarakat dalam mengembangkan Taman Posyandu Sri Rejeki di RW. 09 Kelurahan Kotalama. 


\section{REFORMASI}

ISSN 2088-7469 (Paper) ISSN 2407-6864 (Online)

Volume 9 Nomor 1 (2019)

\section{KESIMPULAN}

Partisipasi masyarakat dalam mengembangkan Taman Posyandu Sri Rejeki di Kelurahan Kotalama Kecamatan Kedungkandang merupakan tipologi partisipasi interaktif karena masyarakat ikut serta dalam pengambilan keputusan, pelaksanaan, pemantauan dan evaluasi, serta turut berpartisipasi dalam pemanfaatan hasil kegiatan. Partisipasi masyarakat disini termasuk dalam ragam partisipasi model 2 yang dianggap bentuk ideal dari 5 model yang ada. tingkat partisipasi masyarakatnya masuk ke dalam tingkatan partisipasi supporting independent community interest atau tingkat memberikan dukungan dalam segala hal. Dukungan informasi, ide, pengambilan keputusan, menjalin kerjasama bahkan dalam hal dukungan dana. Partisipasi masyarakat model seperti ini adalah tingkat tertinggi sehingga kontrol dalam kegiatanpun sangat baik. Hal ini dikarenakan adanya 3 faktor yang mempengaruhi partisipasi yaitu: 1) adanya kesempatan yang diberikan oleh tim penggerak PKK kelurahan, 2) adanya kemauan masyarakat untuk ikut berpartisipasi mengembangkan Taman Posyandu, dan 3) adanya kemampuan masyarakat untuk ikut berpartisipasi terutama untuk menyelesaikan berbagai masalah yang dihadapi dalam mengembangkan Taman Posyandu Sri Rejeki.

\section{DAFTAR PUSTAKA}

Mardikanto, Totok dan Poerwoko Soebianto. 2017. Pemberdayaan Masyarakat dalam Perspektif Kebijakan. Bandung: Alfabeta

Moleong, Lexy J. 2015. Metodologi Penelitian Kualitatif. Bandung: Rosdakarya Sugiyono. 2015. Metode Penelitian Kualitatif dan Kuantitaif. Bandung: Alfabeta Theresia, et all. 2014. Pembangunan Berbasis Masyarakat. Bandung: Alfabeta 